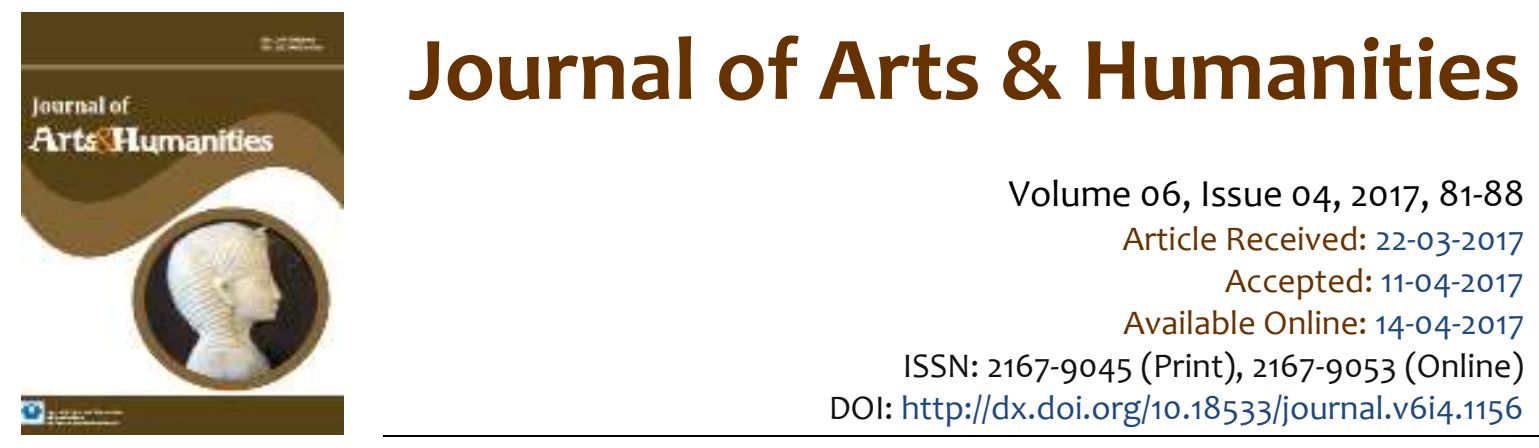

\title{
Translation of Corporate Promotional Materials in view of Skopos Theory ${ }^{1}$
}

\author{
Jing Zheng ${ }^{2}$
}

\begin{abstract}
Chinese businesses have realized the importance of publicity in foreign markets. However, the translation of Chinese corporate promotional materials is not of high quality so far. Multi-facet factors may cause problems in the translation, but the influence of formal equivalence theory on translators can be a big cause. Skopos theory shifts translators' attention from loyalty to the source text to the purpose of the target text, shedding a new light to translation studies. This paper discusses the application of Skopos theory in the translation of Chinese corporate promotional materials and explores the strategies and methods of translating corporate promotional materials from Chinese to English with examples. The study in this paper finds that domestication strategy and translation methods such as restructuring, reduction and reference to paralleled texts are particularly effective to produce a functionally appropriate English translation of Chinese corporate promotional materials. It is suggested that translators apply Skopos theory to their translation practice of corporate promotional materials actively and further research go beyond the discussion of translation strategy and method choice on the part of a translator and study the theory's guidance on all the agents involved in the translation process.
\end{abstract}

Keywords: Corporate Promotional Material, Skopos Theory, Translation Method, Translation Strategy. This is an open access article under Creative Commons Attribution 4.0 License.

\section{Introduction}

Globalization, defined as 'the widening, deepening and speeding up of worldwide interconnectedness in all aspects of contemporary social life' (Held et al., 1999), has caused an unprecedented increase of translation. With the deepening of globalization, companies are getting more and more involved in international business and competition. To succeed in the globalized business world, a company has to publicize itself efficiently among prospective foreign investors and potential consumers in their own language as people's own language continues to be the preferred language for access into information (Bielsa, 2005). High-quality translation of corporate promotional materials which consist of printed

\footnotetext{
1 This research is funded by the Fundamental Research Funds for the Central Universities, No. JB2016094.

2 School of Foreign Languages, North China Electric Power University, Beijing, China.
} 
advertisement, corporate profile, product introduction, etc. can help a company establish a good image and promote sales in the target market. However, though '... translation is all about making connections, linking one culture and language to another, setting up the conditions for an open-ended exchange of goods, technologies and ideas' (Cronin, 2003), its important role in promoting the business and products of a company has been invisible and transparent for years. Influenced by traditional translation theories, translation of Chinese corporate promotional materials is widely viewed as a transfer of information from the source text (ST) to the target text (TT) and neglects the two languages' differences at the linguistic and cultural levels. As a result, the English translation of some Chinese corporate promotional materials are difficult to understand and even unacceptable in the eyes of English readers.

Classification of texts with relation to their function has been conducted for different purposes and on various premises. Texts are generally grouped into three main types in translation studies conventionally with reference to Reiss: informative, operative and expressive, that is, texts may perform an informative, vocative and expressive function (Reiss, 1989). As they carry specific messages that a company desires to deliver to particular readers, corporate promotional materials can be regarded as pragmatic texts which are informative and vocative. The quality of translation of a pragmatic text is evaluated by its accurate transmission of the information and facts on the one hand and the favorable response of its target readers. Due to Chinese and English-speaking people's differences in ways of thinking and expression of ideas, it is evident that some other theories rather than formal equivalence needs to be quoted to translate the messages carried in the Chinese text adequately but not redundantly and to "call upon' the readership to act, think or feel, in fact to 'react' in the way intended by the text" (Newmark, 2001).

Skopos theory proposes that translations are done to fulfill a target-side purpose and the translator's work is a mode of communication that is cross-cultural and mediated, which shifts the focus of translation studies from decoding the meanings from ST and encoding those meanings into TT to the realization of functions of TT. This paper attempts to explore the Chinese-English translation of corporate promotional materials in light of Skopos theory and discusses possible translation strategies and methods to maximize the informative and vocative function of corporate promotional materials with real-world translation examples.

\section{Skopos theory}

Skopos theory was developed in Germany in the late 1970 s as a challenge to the regime of equivalence in translation studies. It's a general shift from linguistic and formal translation theories to a functionally and socio-culturally oriented conceptualization of translation. "Skopos" is the Greek word for "aim" or "purpose" which was introduced to translation theory by Hans J. Vermeer as a technical term for the purpose of a translation and of the action of translating. Skopos theory sees translation as "an international, interpersonal, partly verbal intercultural interaction based on a source text" (Nord, 1997). As an "intentional" activity, translation must be judged according to how well it fulfilled its purpose (Schäffner, 1997). Emphasizing the function of TT, the Skopos theory maintains that all translation should obey three rules, namely, the Skopos rule, the coherence rule and the fidelity rule.

Skopos rule-the core principle of Skopos theory-holds that a translation action is determined by its Skopos which in translation studies usually refers to the communicative purpose of the target text. Any form of translational action may be conceived as a "purposeful activity" (Nord, 1997). Every translation presupposes a commission and is carried out according to a Skopos or commission, which to a large extent is determined by the commissioner or client. The Skopos of the TT and how to realize it are negotiated between the commissioner and the translator. Translation methods and strategies are determined by the purpose and intended function of the TT. The translator is responsible for the final functionally appropriate translation (Vermeer, 2000). While the translator is entitled to decide what role an ST plays in the translation process, "the overall frame of reference for the translator should not be the original and its function, as equivalence-based translation theory would have it, but the function or set of functions the target text is to achieve in the target culture"(Reiss \& Vermeer, 1984). 
The coherence rule indicates that the TT must be comprehensible to readers in the target culture and the communicative situation in which the target text is to be used. It requires the translated text to make sense in the communicative situation in which it is received and be acceptable in a sense that it is coherent with the receivers' situation. Consequently, in the process of translation, the translator should take the target culture into consideration and make necessary alterations to make the translation intelligible.

The fidelity rule means that the ST and the TT should be in accordance with each other on the interlanguage coherence. However, the degree of fidelity depends on the aim of the TT and how the translator understands the ST.

Skopos theory provides a new perspective to translation studies and reflects "a more functional and socio-culturally oriented concept of translation" (Baker, 2001). As the ST is only regarded as an offer of information and the focus is given to the more independent challenges of TT production, Skopos theory has introduced innovation to translation theories. It releases translators from the limitations and a restriction imposed by a narrowly defined concept of loyalty to the ST alone and permits them to adopt translation strategies with reference to the purpose of the TT.

Translation of corporate promotional materials is an intercultural communicative activity where contextual factors surrounding the translation cannot be ignored. These factors include the culture of the intended readers of the TT and of the client who has commissioned it, and, in particular, the function which the TT is to perform in that culture for those readers. Skopos theory focuses on these contextual factors and therefore can be applied to guide the translation of corporate promotional materials.

\section{Features of Chinese corporate promotional materials}

Reiss claims that the type of a text determines its translation. Segmentation of functions of texts could help a translator better understand the source text and thus enhance his translation (Reiss, 1981). Chinese corporate promotional materials, as a type of pragmatic texts, have the following features which should be considered by a translator to achieve the validity of translation.

Chinese corporate promotional materials are rich in contents, covering a wide variety of information from nature of the corporate, history of development, social responsibility to product category, scale of production, etc. However, the detailed introduction to some aspects of the business usually results in a redundant text and a lack of emphasis. Some part of the promotional material may consist of a lot of empty words.

For example, the underlined parts in the following passage means "guided by the Scientific Outlook on Development, China Mobile strives to realize a high degree of unity of business and society, to achieve a comprehensive, coordinated and sustainable development of the Company, the economy and the environment, and to create rich value for relevant parties to achieve harmonious development with them."

中国移动秉承 “正德厚生, 臻于至善”的企业核心价值观, 以“做世界一流企业, 实现从优秀到 卓越的新跨越”战略为指引, 以科学发展观为指导, 努力实现企业经营与社会责任的高度统一, 致力于实现企业在经济、社会与环境方面的全面、协调、可持续发展，为相关方不断创造丰富 价值, 实现和谐发展。

On the other hand, Chinese corporate promotional materials often contain something political and ideological such as the state-owned nature, honors and awards conferred by governmental agencies, inspection by governmental officials and so on. The following is a typical part of Chinese corporate promotional materials which means literally "The rapid and healthy development of $X$ group has received close attention from party and state leaders, experts and scholars. In 2005, Mr. Y, CEO of the Group, was granted an interview by Comrade Z, Chairman of the CPPCC National Committee." 
X集团的持续快速发展, 受到党和国家领导人、各级党委、政府及专家、学者的密切关注。2005 年，公司董事长Y先生受到全国政协主席Z同志的亲切接见。

The above is a word-for-word translation of the Chinese text. However, judged by its communicative skopos, it can't be a good one. Foreign readers may not be very interested in how a business group in China is inspected by governmental officials or its CEO's interview with a political leader. They would like to find from the company's profile some objective information such as its competitiveness, product quality and so on. If they want to know whether a company is worth doing business with, they prefer to refer to comments from people of the same trade rather than a company's relationship with governmental officials.

What's more, Chinese corporate promotional texts tend to state facts in the third person with formal wording, making them sound as true and objective as a news report. For example,

1912 年 2 月, 经孙中山先生批准, 中国银行正式成立。从 1912 年至 1949 年, 中国银行先后行 使中央银行、国际汇兑银行和国际贸易专业银行职能，坚持以服务社会民众、振兴民族金融为 己任，历经磨难，艰苦奋斗，在民族金融业中长期处于领先地位，并在国际金融界占有一席之 地。

Bank of China was formally established in February 1912 following the approval of Dr. Sun Yat-sen. From 1912 to 1949 , the Bank served consecutively as the country's central bank, international exchange bank and specialized international trade bank. Fulfilling its commitment to serving the public and developing China's financial services sector, the Bank rose to a leading position in the Chinese financial industry and developed a good standing in the international financial community, despite many hardships and setbacks.

The above features of Chinese corporate promotional materials can be explained by the Chinese culture and the thinking pattern of Chinese consumers. However, to achieve the same informative and appellative effects in the target culture of English-speaking people, some special techniques and strategies of translation should be applied.

\section{Strategies and methods of translating company promotional materials}

\subsection{The strategy of domestication and foreignization}

Domestication and foreignization are two fundamental translation strategies proposed by American translation theorist L. Venuti. In Venuti's view, domestication is an ethnocentric reduction of the foreign text to target-language cultural values, bringing the author back home, while foreignization is an ethnodeviant pressure on those (cultural) values to register the linguistic and cultural difference of the foreign text, sending the reader abroad (Venuti, 1995). Generally speaking, domestication designates the type of translation in which a transparent, fluent style is adopted to minimize the strangeness of the foreign text for target language readers, while foreignization means a target text is produced which deliberately breaks target conventions by retaining something of the foreignness of the original (Shuttleworth \& Cowie, 1997).

Corporate promotional materials are used to provide potential foreign customers with products, services and business-related information so as to establish a good image for the business and attract purchases. When translating corporate promotional materials, intended readers' perception and comprehension of the translation must be focused on. With the domestication strategy a translator can overcome the barriers caused by cultural and linguistic differences, presenting a readable, valid and comprehensible translation to intended readers and thus realize the TT's function of business communication.

\subsection{Restructuring}


Restructuring is a dramatic adjustment used to improve the readability of the target text according to the idiomatic usage of the target language. Adjusting the sequence of sentences and paragraphs in terms of chronicle, and logical order, adding titles or subtitles, changing the format or layout of the source text are common ways of restructuring the source text so that its translation can be more reader-friendly and coherent as a whole. The following is an example of restructuring the contents of corporate promotional materials.

XXX 公司是一家拥有生产、贸易与研发的综合企业 (a)。我们主要经营药材、食品与饲料添加 剂等, 产品主要出口欧洲、美国、澳大利亚、中东、非洲等国 (b)。我们尤其擅长研制与出口 维他命与抗生素的原材料(c)。我们的维他命以及相关产品的出口量达到 1500 公吨, 能够确保 根据市场以及客户的需求来按时安排订单、运输 (d)。另外, 我们的市场研发中心能给客户提 供信息资讯服务、告知客户国内产品与市场的现状，以便客户能够更多了解中国国情、做出更 准确的判断与决策 (e)。

目前最热销的有抗坏血酸系列 (维生素 C、包衣维生素 C......) ( f f)。我们将以卓越的标准以及 完善的服务帮助我们的客户在市场上获得最强的竞争力 $(\mathrm{g})$ 。我们希望能够与来自国内外的 新老朋友一起携手共创美好的未来 $(h)$ 。

In the first paragraph of the Chinese text, sentence $a$ and $b$ are a general introduction of the company. Sentence $c$ is about the products, while sentence $d$ and e talk about service commitments. However, in the second paragraph, best selling products are introduced (sentence $f$ ) and more commitments are made in sentence $g$. The ending part is an invitation for future cooperation (sentence $g$ and $h$ ).

The original text seems to be loose in structure. The restructured one is as follows,

The $1^{\text {st }}$ paragraph —a general introduction to the company (sentence $a$ and $b$ );

The $2^{\text {nd }}$ paragraph —an introduction to products (sentence $\mathrm{c}$ and $\mathrm{f}$ );

The $3^{\text {rd }}$ paragraph—service commitments (sentence $d$ and e);

The $4^{\text {th }}$ paragraph—an invitation for future cooperation (sentence $g$ and $h$ ).

The translation is as follows:

XXX specializes in researching, manufacturing and marketing raw materials of pharmaceutical, food and feed additives. We mainly export to countries and regions including Europe, America, Australia, Mid-east and Africa.

We are especially expert in the raw materials of vitamins and antibiotics. Currently, our best-sellers are Ascorbic Acid Series (such as Vitamin C, Coated Vitamin C...)

We are capable of arranging prompt manufacturing and shipment for orders as big as $1500 \mathrm{MT}$ vitamins and related products. Moreover, our marketing center can provide our clients with specific information on China's market so they can make more informed decisions.

We are convinced that our commitment to quality and service will give you more competitiveness in the marketplace. We look forward to joining hands with businesses and individuals from both China and abroad to create a brighter future (Wu \& Zhang, 2011).

\subsection{Reduction}

Reduction is a most widely accepted method of translating a redundant ST. When the materials to be translated are overloaded with cultural factors or information that may never interest the intended readers, for example, political slogans, geographical locations, and so on, it is advisable that these parts should be reduced or removed because literal translation, although "faithful" to the original form of the text, will undermine the readability of the translation and confuse the target readers.

这是一个千帆竞渡、百舸争流的伟大时代。万里昆仑谁丵破, 无边波浪拍天来。纵观当今世界 风起云涌的国际经济贸易浪潮, 波澜壮阔, 气象万千, 逆水行舟, 不进则退, 唯有革故鼎新, 方能永不衰败。山东东方公司...... 
This opening part of a company introduction involves in many ancient poems and idioms of China, which can impress Chinese readers and enable readers to perceive the grand vision of the company. However, when the target readers are English-speaking people, this passage, if translated literally, may sound full of flourishing rhetoric and empty words. Taking the informative and vocative function of corporate promotional materials into consideration, a translator is advised to reduce the poems and idioms in his translation and translate the information implied by them. A suggested translation is as follows.

This is a great era, full of opportunities and competition. Therefore, only by reforms and innovations can we survive the fierce competition and stand out in the international market. (Chang, 2010)

\subsection{Referring to paralleled texts}

Paralleled texts can serve as a good reference to translators of Chinese corporate promotional materials. Rewriting the source material according to the structure, mood and expressions can cater to the thinking pattern and reading habit of intended readers, thus achieving the communicative and publicist purpose of transition.

上汽集团的愿景是: 为了用户满意, 为了股东利益, 为了社会和谐, 上汽集团要建设成为品牌 卓越、员工优秀，具有核心竞争能力和国际经营能力的汽车集团。

The above text is originally translated as "SAIC vision: For the satisfaction of our customers, for the interest of our shareholders, for the harmony of our society, we will build SAIC into an automotive company with outstanding brands, brilliant employees, core competitive competencies and international operation capabilities."

Some paralleled texts found are as follows:

"Our vision: "We want to satisfy all our customers' financial needs and help them succeed financially." (Wells Fargo \& Company)";

"As a company and as individuals, we take great pride in contributing to the communities where we live and work. (Chevron)"

With reference to the above two passages, the translation can be revised into the following one.

Our vision: "We want to satisfy all our customers' needs and we take great pride in contributing to the communities where we live and work. Our people, technical expertise, financial strength, and global scope will help SAIC become a world-class automotive provider." (Lu, 2012)

It should be noted that the above-mentioned strategies should never be misunderstood as a translator's privilege endowed by Skopos theory of adding or deleting material at will in accordance with the Skopos of TT. As mentioned above, the Skopos of translating a given text is decided by the client and translator. A translator receives the basic information and instructions before carrying out those instructions freely. The instructions or commission specify the goal or purpose of a piece of translation. The translator must interpret ST information "by selecting those features which most closely correspond to the requirements of the target situation" (Shuttleworth and Cowie, 1997).

\section{Conclusions and suggestions}

\subsection{Conclusions}

A text is made meaningful by its receiver and for its receiver. Different receivers find different meanings in the same linguistic material offered by the text. What the translator can do, and should do, is to produce a text that is at least likely to be meaningful to target-culture receivers. In this sense, Skopos theory sheds a light into the translation practice of corporate promotional materials whose purpose is to communicate with potential consumers in writing. 
To achieve the informative, communicative and vocative purpose of the English translation of Chinese corporate promotional materials, the domestication strategy and translation methods such as restructuring, reduction and paralleled texts are applicable in the translation process to reduce political or ideological elements and redundant information in the ST and transmit the objective information and facts in the target language.

\subsection{Suggestions}

Translation serves as the infrastructure of connecting Chinese companies with the global market. The high-quality translation of corporate promotional materials must be highlighted to achieve the ultimate objective of attracting business and cooperation through corporate publicity. As translators shoulder the responsibility of producing the final translation, they are advised to apply Skopos theory to translation practice consciously and deal with the relationship between ST and TT properly. An accurate judgment of the Skopos of TT is the prerequisite of producing a qualified translation. To determine what effects the TT is expected to invoke among the target readers, translators need to consult and negotiate with clients before starting translation. Furthermore, translators of corporate promotional materials should acquire knowledge on business and culture while familiarizing themselves with paralleled texts to overcome difficulties in translation caused by knowledge gap and cultural differences.

Skopos theory has been criticized for allowing the end to justify the means in the translation process. This would make this theory inappropriate to the translation of texts-such as literary or religious translation-that are largely determined by the author's personal intention. But it is undeniable that for the translation of pragmatic texts like corporate promotional texts whose function is informative and vocative, Skopos theory can provide constructive guidance. Further study could go beyond the discussion of translation strategy and method choice on the part of a translator and study the theory's guidance on all the agents involved in the translation process.

\section{References}

Baker, M. (Eds.) (2001).The Routledge Encyclopedia of Translation Studies. London \& New York: Routledge. Bielsa, E. (2005). Globalization and Translation: A Theoretical Approach. Language and Intercultural Communication, 5:2, 131-144.

Chang, Yutian (2010). Creative Translation of Business from Chinese to English. Beijing: University of International Business and Economics Press (in Chinese).

Cronin, M. (2003).Translation and Globalization. London: Routledge.

Held, D., McGrew, A., Goldblatt, D. and Perraton, J. (1999). Global Transformations .Cambridge: Polity Press.

Lu, Xiaojun (2012). A Comparison of Chinese and American Company Profile and Translation. Chinese Translators Journal. No.1 (in Chinese).

Newmark, P. (2001). A Textbook of Translation. Shanghai: Shanghai Foreign Language Education Press.

Nord, C. (1997). Translating as a purposeful activity: Functionalist approaches explained. Manchester: St. Jerome.

Reiss, K. (1981/2003). Type, Kind and Individuality of Text: Decision Making in Translation. Translated by S. Kitron, In L. Venuti (Eds.), The Translation Studies Reader (pp. 160-171). London: Routledge.

Reiss, K. (1989). Text Types, Translation Types and Translation Assessment. In Chesterman A. (Eds.), Readings in Translation Theory (pp. 105-114). Finland: Oy Finn Lectura Ab.

Reiss, K. and Vermeer, H. J. (1984). Groundwork for a General Theory of Translation. Tubingen: Niemeyer.

Schäffner, C. (1997). From 'Good' to 'Functionally Appropriate': Assessing Translation Quality. Current Issues in Language and Society, Vol. 4, No 1, 1-5.

Shuttleworth, M. \& Cowie, M. (1997). Dictionary of Translation Studies. Manchester, UK: St Jerome Publishing.

Venuti, L. (1995). The Translator's Invisibility: A History of Translation. London \& New York: Routledge. 
Vermeer, H. J. (2000). Skopos and commission in translational action. In L. Venuti (Eds.), The Translation Studies Reader (pp. 221-233). London: Routledge.

Wu, Jian \& Zhang, Yunfei (2011). Translation of Corporate Promotional Materials into English: A Multilevel Structuring Process. Shanghai Journal of Translators, No.1 (in Chinese). 